\title{
Growth Pattern of Pseudomonas aeruginosa in different wastewater media
}

\author{
Aderiye Babatunde Idowu; Oluwole Olusola Adeoye*, Sulaimon Adebisi M, Bello \\ Mustapha Oladapo
}

Department of Microbiology, Ekiti State University, Ado-Ekiti

\begin{abstract}
Restaurant wastewater are a major cause of environmental pollution with the indiscriminate release of the effluent to the environment resulting in blocking of drainages and eutrophication thereby causing serious threat to aquatic life. The growth pattern of a dietary rich oily wastewater degrading bacteria strain, Pseudomonas aeruginosa in different wastewater media composed to mimic the possible constituents of restaurant wastewater was investigated in this study. There was noticeable microbial growth in the synthetic and domestic wastewaters after $48 \mathrm{~h}$ while the detergent wastewater and heated oil-detergent wastewater did not support the strain's growth. The decrease in the fat content with a corresponding increase in the ash content after 120h was due to the test strain's metabolic activity, which is slightly higher in domestic wastewater than the heated oildetergent solution. Also, the potassium $\left(\mathrm{K}^{+}\right), \mathrm{Mg}^{2+}, \mathrm{Fe}^{2+}$ and $\mathrm{Ca}^{2+}$ contents increased within the same period in both media except in the domestic wastewater where the $\mathrm{Ca}^{2+}$ content reduced. Protease enzyme activity (46.440mM/min) was considerably higher in the domestic wastewater than lipase $(3.322 \mathrm{mM} / \mathrm{min})$ and amylase activity (14.244mM/min) after 72 hours of incubation. The pristine genetic properties of Pseudomonas aeruginosa altered when cultured in various wastewaters probably due to variation in the composition of the substrates.
\end{abstract}

Keywords - restaurant, domestic wastewater, Pseudomonas aeruginosa, synthetic wastewater, lipase, 16s rRNA sequencing.

\section{INTRODUCTION}

Restaurant wastewater usually results from water that has been used for cleaning food products such as meats and vegetables, washing dishes and cooking utensils, or cleaning the floor of restaurants (Zulaikha et al., 2014). The effluent comprises leftovers of food, soup, detergents, fats, oil and grease which generates unpleasant odor when released into drains without proper pretreatment processes (Xue et al., 2016).

The domestic wastewater is composed of proteins and carbohydrates, smaller amounts of lipids (Odeyemi et al., 2011), anthropogenic organic chemicals and some microbial pathogens (Tchobanoglous et al., 1991). The lipids (oils) that are released into the environment have been reported to be responsible for the clogging of sewer networks and unsettling the balance of water in the treatment plants and implicated as environmental pollutants (Saifudin et al., 2006; Xue et al., 2016).

Several authors have reported different wastewater contaminants in soil and aquatic environments in different parts of Nigeria (Nwachukwu et al., 2001; Adeyemo, 2003; Akpan, 2004; Efe, 2005; Zulaikha et al., 2014). In Nigeria, domestic wastewater especially from bukateria undergoes little treatment (Adeyemo, 2003). It is usually disposed on open lands or drainages where it empties into water bodies causing eutrophication (Akpan, 2004). Studies have shown that the chemical oxygen demand (COD) concentration, animal and vegetable oils and suspended solids are 16 times higher in restaurants wastewaters than domestic wastewater (Fadile et al., 2011; Kshirsagar, 2013; Xue et al., 2016) Leaching into groundwater is also a major part of environmental concern, especially due to the recalcitrant nature of some contaminants (Lapygina et al., 2002).

Biodegradation of fats and oils in wastewater has a potential role in pollution control employing the metabolic capacity and diversity of microorganisms to breakdown these complex substrates and reduce its toxicity (Nelson, 2009). Bioremediation offers a clean and cheaper alternative to conventional clean-up methods (Zhu et al., 2001; Xia et al. 2006; Calvo et al., 2008).

Lipase producing bacteria have been isolated from oil contaminated sites and exploited for their ability to remediate domestic wastewater polluted environments (Odeyemi and Aderiye, 2011). The bioremediation process is typically enzymatic, where amylases, oxygenases and lipases are secreted into the medium which facilitate the breakdown. Predominant among degraders of complex organic substrates including lipids and oils is the genus Pseudomonas which has been investigated for its ability for bioremediation (O'Mahony, 2006; Odeyemi and Aderiye, 2011). With domestic oil waste constituting a big threat to clean and hygienic environment in Nigeria, there is need to further exploit the potential of Pseudomonas aeruginosa previously 
associated with the degradation of oil rich waste water (Odeyemi et al., 2014).

Therefore, this study was aimed at observing the growth pattern of $\mathrm{P}$. aeruginosa in different wastewater media and monitoring the effect of some growth conditions on the genetic makeup of the microbe.

\section{HEADINGS}

Collection of domestic oil wastewater

Fresh wastewater samples containing a mixture of waste food debris, detergents and domestic oils were collected into sterile $2.5 \mathrm{~L}$ sampling bottles from Falegan restaurant situated along Ekiti State Secretariat road, Ado-Ekiti, Ekiti State of Nigeria. The restaurant opens between $8 \mathrm{am}$ and $4 \mathrm{pm}$ daily and samples were collected at $2 \frac{1}{2} \mathrm{~h}$ intervals (10:30am and $1 \mathrm{pm}$ and 3:30pm). The samples were transported in cold storage to the Microbiology laboratory of the Ekiti State University, Ado-Ekiti for further analyses.

\section{Source of Pseudomonas aeruginosa}

$P$. aeruginosa was obtained from the work of Odeyemi $e t$ al. (2013), previously isolated from domestic oil-rich wastewater sample collected from the same source and purified by sub-culturing on Pseudomonas agar (HiMedia, India).

\section{Preparation and analyses of wastewater media}

The growth culture media for $P$. aeruginosa include restaurant wastewater, palm oil/detergent solution, detergent solution and synthetic wastewater. Two hundred millilitre $(200 \mathrm{~mL})$ of fresh restaurant wastewater was homogenized and sieved before autoclaving to prepare sterile wastewater media. For preparation of palm oil/detergent solution, $20 \mathrm{~mL}$ of palm oil was heated for 15 minutes in a ventilated oven at $100^{\circ} \mathrm{C}$, allowed to cool and $20 \mathrm{~g}$ of detergent (OMO Unilever PLC.) was mixed with the heated palm oil and then dissolved in $200 \mathrm{~mL}$ of distilled water in $1000 \mathrm{~mL}$ Erlenmeyer flask prior to autoclaving. Detergent solution was prepared by dissolving $20 \mathrm{~g}$ of the detergent in $100 \mathrm{~mL}$ of distilled water, made up to $200 \mathrm{~mL}$ in $250 \mathrm{~mL}$ Erlenmeyer flask before autoclaving. Synthetic wastewater was formulated using a modification of the method of Foglar (2004) by dissolving $1 \mathrm{~g}$ of sodium acetate, $0.1 \mathrm{~g} \mathrm{MgSO}_{4} .7 \mathrm{H}_{2} \mathrm{O}, 0.1 \mathrm{~g}$ $\mathrm{KNO}_{3}, 0.1 \mathrm{~g} \mathrm{KH}_{2} \mathrm{PO}_{4}, 0.2 \mathrm{~g}$ meat extract and $0.1 \mathrm{~g} \mathrm{NaCl}$ in $200 \mathrm{ml}$ of distilled water prior to autoclaving. The media were then inoculated with the test strain.

Twenty millilitre $(20 \mathrm{~mL})$ of standard inoculum was transferred into each of the four media, incubated at $30^{\circ} \mathrm{C}$ and monitored spectrophotometrically for 5days at $24 \mathrm{~h}$ intervals. Also, the microbial load, proximate components (moisture, ash, crude protein, crude fibre, fat and total carbohydrate contents) (AOAC, 2005) and mineral analyses $\left(\mathrm{Fe}^{2+}, \mathrm{K}^{+}, \mathrm{Ca}^{2+}, \mathrm{Mg}^{2+}\right)(\mathrm{AOAC}, 2005)$ were carried out during the same period.

\section{Analysis and Production of Enzymes:}

The wastewater media was prepared for enzyme production, with $100 \mathrm{~mL}$ of each wastewater inoculated into five different $250 \mathrm{~mL}$ flasks, incubated in an orbital shaker (Stuart shaker) at 150 r.p.m and $30^{\circ} \mathrm{C}$. Samples were drawn from each of the flasks at $6 \mathrm{~h}$ intervals for a period of $48 \mathrm{~h}$ and each sample was centrifuged at 5000 $\mathrm{rpm}$ for $30 \mathrm{~min}$ at $4^{\circ} \mathrm{C}$. Cell free supernatant corresponding to each growth phase was used for the assay of crude enzyme (An et al., 1994). The activity of protease and amylase was determined according to the methods of An et al. (1994) and Berfield et al. (1995) respectively while lipolytic activity was determined by colorimetric method of Lotrakul and Dharmsthiti (1997).

\section{Molecular characterization of $P$. aeruginosa (CP004061.1) grown in different wastewater media}

Genomic DNA was isolated according to the method of Sambrook et al. (1989). The appropriate primer used for the work was designed by Inqaba Biotechnical Industries (South Africa). DNA isolation, PCR and sequencing were carried out at the International Institute for Tropical Agriculture (IITA, Ibadan, Nigeria). The sequences were analyzed using the BLAST (Basic Local Alignment Search Tool) bioinformatics program on the NCBI (National Center for Biotechnology Information) website.

\section{RESULTS AND DISCUSSION}

The growth and the degrading potential of Pseudomonas aeruginosa (CP004061.1) was monitored in different wastewater media for about $120 \mathrm{~h}$. This bacterial strain recovered from restaurant wastewater, after dish washing (with soap solution, $5 \mathrm{~g} / 100 \mathrm{ml}$ detergent in water), first and second rinsing of the dishes, and run-off into open sewers along the drainage was capable of growing well in dietary oil (Odeyemi et al., 2014).

The synthetic wastewater and detergent solution were used as experimental controls. It was observed that the synthetic media was best suited for the growth of the organism after $144 \mathrm{~h}$ when compared to other media. There was about $553 \%$ increase in microbial growth than when cultured in the domestic wastewater. Meanwhile, there was no visible growth in either the detergent wastewater or the heated detergent wastewater (Figure 1). However, Odeyemi et al. (2013) reported that this Pseudomonas strain was capable of growing in detergent concentration as high as $5 \mathrm{~g} / 100 \mathrm{ml}$ which is lower compared to the $20 \mathrm{~g} / 100 \mathrm{ml}$ used in this study. Ambilly et al. (2014) reported the growth of Pseudomonas 
aeruginosa (MTCC 10311) in 96\% of Sodium dodecyl sulfate after $48 \mathrm{~h}$ incubation in detergent contaminated soil.

The various mineral salts present in the synthetic wastewater might have influenced the high count of the Pseudomonas sp. (Usharani et al., 2011). Odeyemi et al. (2013) also reported an appreciable increase in the weight of Pseudomonas aeruginosa with $66.7 \%$ weight gain after 5 days incubation in domestic oil wastewater. The increase in the weight may be attributed to the ability of the strain to produce lipase which is responsible for dietary oil degradation.

The nutritive quality of any medium is better evaluated by assessing its proximate composition which provides information on the basic chemical components of the medium and the type of growth that takes place within such medium (Adeolu and Enesi, 2013). The nutritive qualities of the fresh heated oil/ detergent wastewater and domestic wastewater were examined. Similarly, these qualities were investigated after $144 \mathrm{~h}$ incubation.

The proximate components of the culture media revealed that the ash content increased in both the synthetic and domestic waste water after $120 \mathrm{~h}(0.16 \%$ to $0.24 \%$ and $0.21 \%$ to $0.26 \%$ respectively). However, the crude protein was found to decrease in the synthetic wastewater $(0.45$ $0.37 \%$ ) but increased in the domestic wastewater $(0.38$ $0.40 \%$ ). Also, there was reduction in the fat content of both media ( 0.11 to $0.07 \%$ and 0.10 to $0.06 \%$ respectively). There was however no significant difference in the moisture content in the synthetic wastewater and the domestic wastewater $(0.02 \%)$ (Table 1). This report is similar to that of Odeyemi et al. (2014) where a low value of $3.2 \%$ crude protein, $3.1 \%$ carbohydrate and $1.2 \%$ fat was reported in the domestic waste water. The low organic matter observed might be due to variation in the organic components in the wastewater.

Ash content provides an estimate of the inorganic quality of a substrate (Adebowale and Bayer, 2002; Adeolu and Enesi, 2013). There was notable increase in the ash content of the two wastewater media after $120 \mathrm{~h}$ incubation as shown in Table 1 . The various activities of Pseudomonas aeruginosa on the organic component of the wastewater are likely responsible for the level of ash detected in the wastewater medium. Tchobanoglous et al. (1991) indicated that the organic matter in wastewater is mostly composed of proteins and carbohydrates and smaller amounts of lipids. The rate of microbial activity (fermentation) on the fibre content of the wastewater sample may have contributed to the slight increase in the carbohydrate and ash contents. This study also revealed the low crude protein content of the domestic wastewater and the heated oil/detergent wastewater during incubation. This observation is contrary to the findings of Effiong et al. (2009), who reported high values (between $26.2 \%$ and $36.8 \%$ ) for ash in wastewater after treatment. According to Hanif et al. (2006), these amounts may be attributed to high nitrogen contents in those wastewaters with vegetables.

The mineral concentrations of both the heated oil/domestic and domestic oil wastes also increased after $120 \mathrm{~h}$. There was increase in the potassium $\left(\mathrm{K}^{+}\right) 7.20 \mathrm{mg} / \mathrm{L}$ - $7.50 \mathrm{mg} / \mathrm{L}(4.2 \%), \mathrm{Mg}^{2+}(25.00 \mathrm{mg} / \mathrm{L}-28.10 \mathrm{mg} / \mathrm{L})$ (12.4\%), $\mathrm{Ca}^{2+}(11.30 \mathrm{mg} / \mathrm{L}-11.35 \mathrm{mg} / \mathrm{L})(0.4 \%)$ and $\mathrm{Fe}^{2+}$ $(0.01 \mathrm{mg} / \mathrm{L}-0.03 \mathrm{mg} / \mathrm{L})(200 \%)$ in the heated oil/detergent wastewater after $120 \mathrm{~h}$. Similarly, there was slight increase in the potassium content $(6.50 \mathrm{mg} / \mathrm{L}-7.00 \mathrm{mg} / \mathrm{L})(7.7 \%)$, $\mathrm{Mg}^{2+}(27.01 \mathrm{mg} / \mathrm{L}-29.30 \mathrm{mg} / \mathrm{L})(8.5 \%), \mathrm{Fe}^{2+}(0.01 \mathrm{mg} / \mathrm{L}-$ $0.03 \mathrm{mg} / \mathrm{L})(200 \%)$ in the domestic oil wastewater. Meanwhile, calcium reduced significantly $(99.75 \%)$ from $(12.00 \mathrm{mg} / \mathrm{L}-0.03 \mathrm{mg} / \mathrm{L})$. Phosphorus was not detected in both media. The increase in the mineral contents of the waste media may be responsible for the high ash content observed after $120 \mathrm{~h}$ in the waste media (Table 2).

Similar report was obtained by Odeyemi et al. (2013) where the mineral content of the domestic wastewater rose on the ninth day of degradation of the samples. Despite the low mineral contents, the media were still rich enough to support microbial growth due to low nutrient demand of microorganisms.

The $\mathrm{pH}$ and temperature of the wastewater culture media were also monitored. There was no significant change in the temperature of the media, which averaged $27.25^{\circ} \mathrm{C}$. However, there was a significant drop in the $\mathrm{pH}$ of the media except the synthetic media. Synthetic wastewater showed a $\mathrm{pH}$ range of $8.80-10.24$, while the $\mathrm{pH}$ values in the domestic wastewater varied between 9.06 and 10.5; detergent wastewater varied between 9.85 and 11.31 and the heated oil wastewater between 8.75 and 11.15 (Fig. 2).

The various biochemical reactions that took place within the medium depend on the enzymes which facilitate the processes (Kirk et al., 2005). The activity of the enzymes (amylase, lipase and protease) secreted by Pseudomonas aeruginosa into the growth media during incubation was examined at different time intervals. The activities of these enzymes increased during the incubation of domestic oil waste water. It was however observed that lipase activity $(0.333,2.778$ and $3.322 \mathrm{mM} / \mathrm{min})$ in the domestic wastewater was low when compared to amylase and protease activities. The results obtained for lipase activity were similar to those of Orapin et al. (2002) who reported higher fat $(73 \%)$ and oil $(88 \%)$ degradation in the wastewater treated with a pure culture of Pseudomonas aeruginosa after 7days. 
Amylase activity in the domestic oil waste water was $378.4 \%$ greater $(14.24 \mathrm{mM} / \mathrm{min})$ after $120 \mathrm{~h}$ storage than its initial value with protease activity exhibiting a tremendous influence on biodegradation of the waste water $(46.44 \mathrm{mM} / \mathrm{min}$ after $120 \mathrm{~h})$. Meanwhile, Laura et al. (2013) reported some toxicity impacts of sewage effluent on the amylase activity of pigeon pea (Cajanus cajan L.) in $50 \%$ and $100 \%$ sewage effluent for 8days. Interestingly, a corresponding increase in the protein concentration in the waste water was recorded after $120 \mathrm{~h}$ $(41.82 \mathrm{mg} / \mathrm{ml})$. The protease activity in the domestic oil wastewater was similar to the report of Irina and Yana (2010) who observed an accelerated increase in protein hydrolysis and the rate of protein removal from $10 \%$ to an average of $74 \%$ within $72 \mathrm{~h}$ in kitchen wastewater treated with proteolytic bacteria which without the organism would have taken $135 \mathrm{~h}$. The high production of protease can be attributed to the meat, fish and other proteinaceous foods present in the domestic wastewater (Table 3).

The recovered genomic DNA extracted from the strain grown at optimal conditions in the different wastewater samples was studied. The entire $1.5 \mathrm{~kb} 16 \mathrm{~S}$ rRNA gene was amplified (Figure 2) and sequenced. A search of the Genbank using the BLAST tool showed that the pristine strain cultured in the heated oil wastewater and in the domestic wastewater, at $98 \%$ identity value and $0.0 \mathrm{E}$ value was similar to Pseudomonas sp. (R3. 1B) and Pseudomonas sp. strain (PO150) respectively. Also, it showed $98 \%$ identity value and 0.0 E-value similarity and 97\% identity value and 0.0 E-value similarity with Pseudomonas sp. strain (YR20) and Pseudomonas sp. strain (PO150) respectively, after BLAST.

Sequences reported here are available at the Genbank Nucleotide Sequence Database under the accession numbers KM058081.1, HG93439.1, HM224401.1 and KC433649.1 respectively.

The 16s rRNA sequencing analysis revealed that the Pseudomonas sp. strain (PO150) was present in both the domestic wastewater and synthetic wastewater and these can be named Pseudomonas sp. strain (PO150a) and Pseudomonas sp. strain (PO150b) respectively to distinguish them. Pseudomonas sp. (PO150b) had the highest degrading activity and this might be attributed to the composition of the synthetic wastewater (Figure 3). This is in agreement with high cell concentration observed in the synthetic medium after 120hours incubation.

The PCR reveals that there has been genetic modification in the pristine Pseudomonas strain when grown in domestic wastewaster and heated oil/ detergent media (Fig. 3). The molecular weight of the pristine isolate and synthetic media DNA sequence was around $0.75 \mathrm{kbp}$ compared to that from the same isolate grown in domestic wastewater and heated oil/ detergent media which was about $1.5 \mathrm{kbp}$ thus suggesting that the conditions present in the culture media of the domestic wastewater and heated oil/ detergent media may have affected the genome sequence. The nucleotide sequence tree relates the similarity of all the isolates; Pseudomonas sp. strain (Heated), Pseudomonas sp. strain (Domestic), Pseudomonas sp. strain (Pristine) Pseudomonas sp. strain (Synthetic) grown under the same condition in wastewater media.

\section{FIGURES AND TABLES}

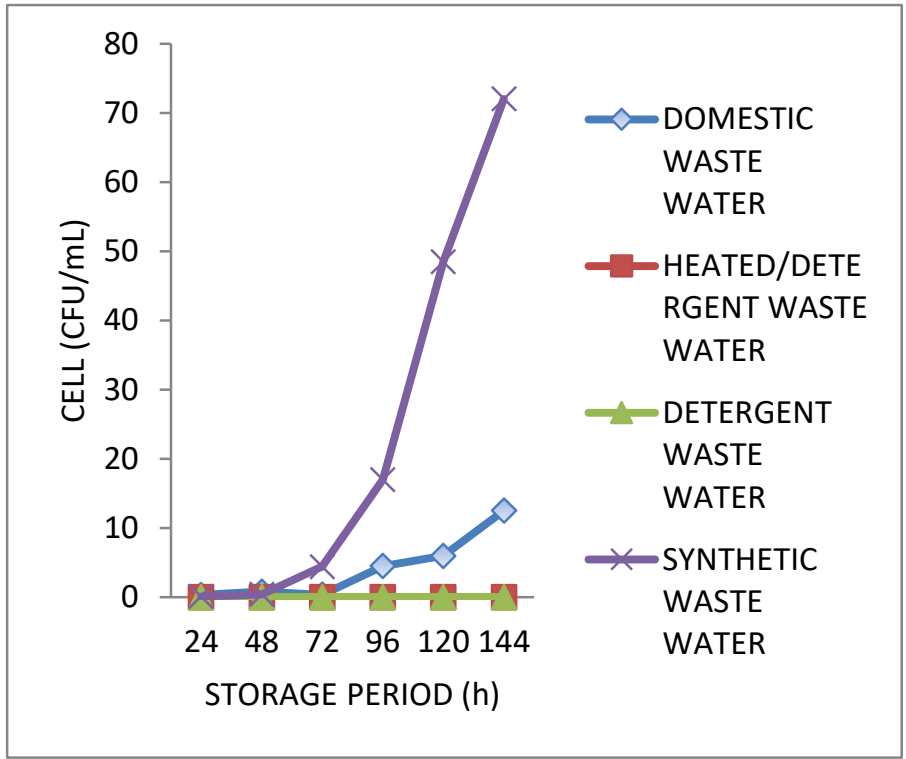

Figure 1: Growth of Pseudomonas aeruginosa in the different media

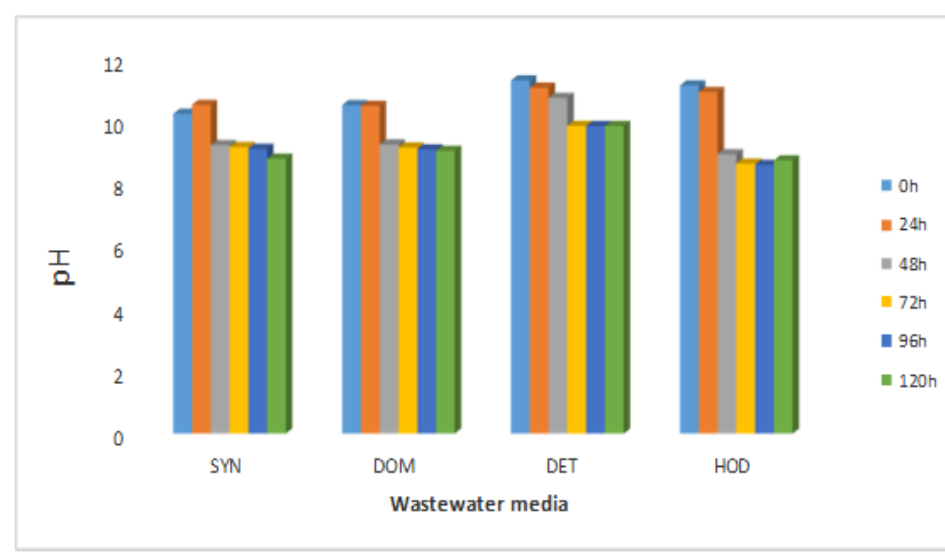

Legend: SYN (synthetic media), DOM (domestic oil wastewater media), DET (detergent wastewater media), HOD (heated oil detergent wastewater media)

Fig.2: The $\mathrm{pH}$ values of the wastewater media 


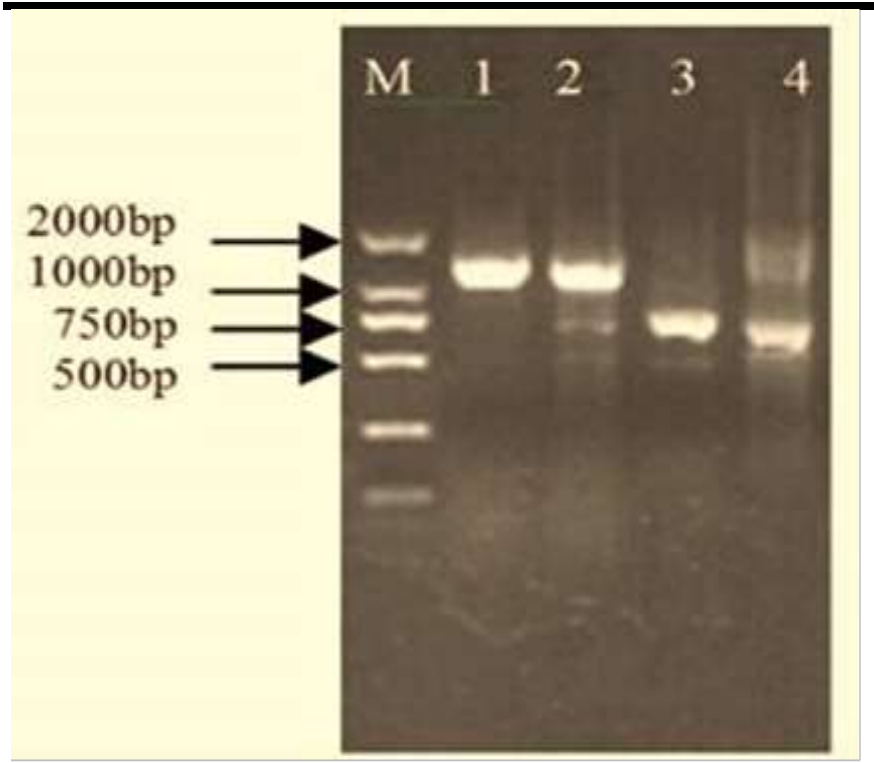

Fig.3: PCR results of the amplified genomic DNA of Pseudomonas aeruginosa.

Keys: M-DNA ladder: 2000bp, 1- Pseudomonas sp. (Domestic), 2- Pseudomonas sp. (Heated), 3Pseudomonas sp. (Pristine) and 4- Pseudomonas sp. (Synthetic).

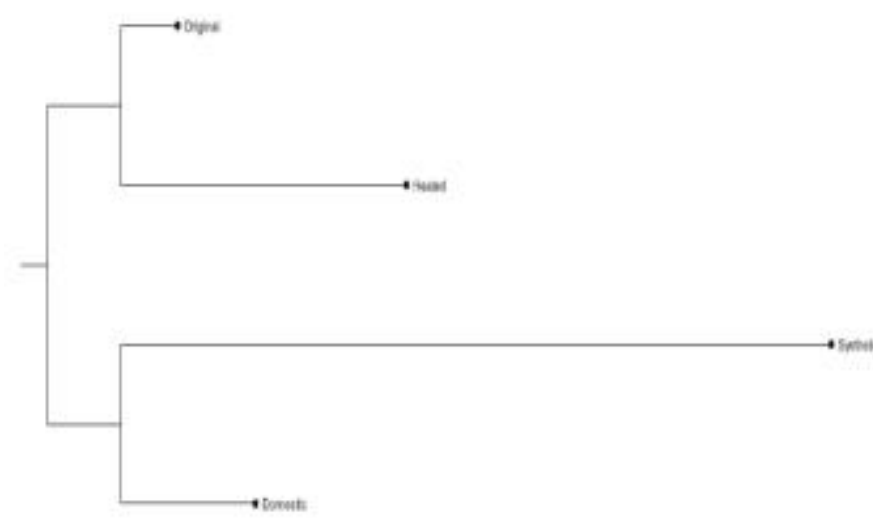

Fig.4: Nucleotide sequence tree of the Pseudomonas aeruginosa

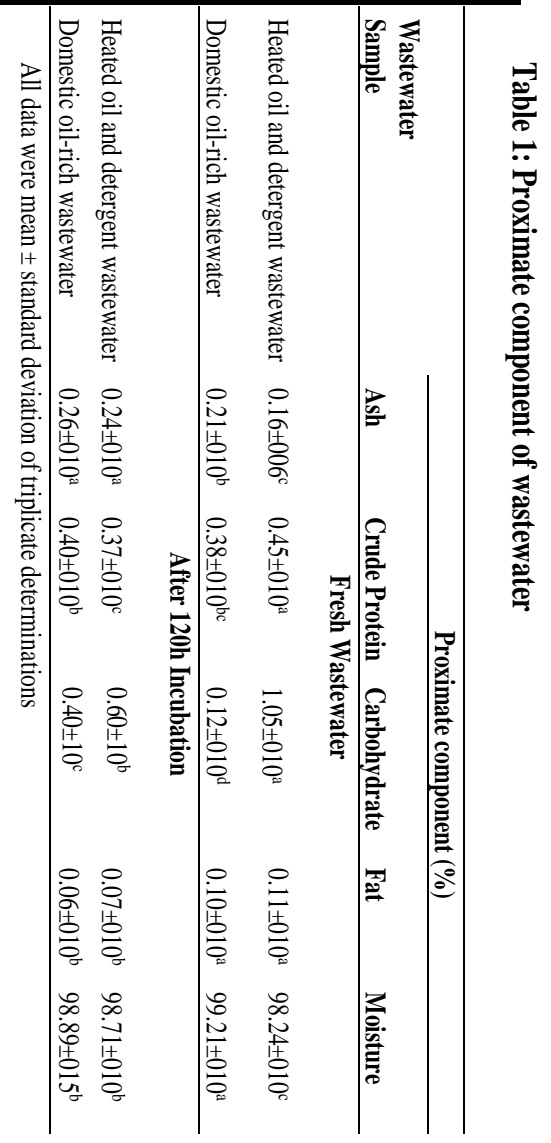

\section{CONCLUSION}

Microbial communities are prone to adapt to a substrate when it is a regular contaminant, such is the situation for the Pseudomonas sp. inoculated into the wastewater media. The genetic sequence of the original inoculum changed when grown in the different wastewater media which might be due to the variations in the media composition since the organism was exposed to the same environmental conditions. However, the nature and mechanism of the genetic changes of this organism in the different growth media is still open to investigation. 


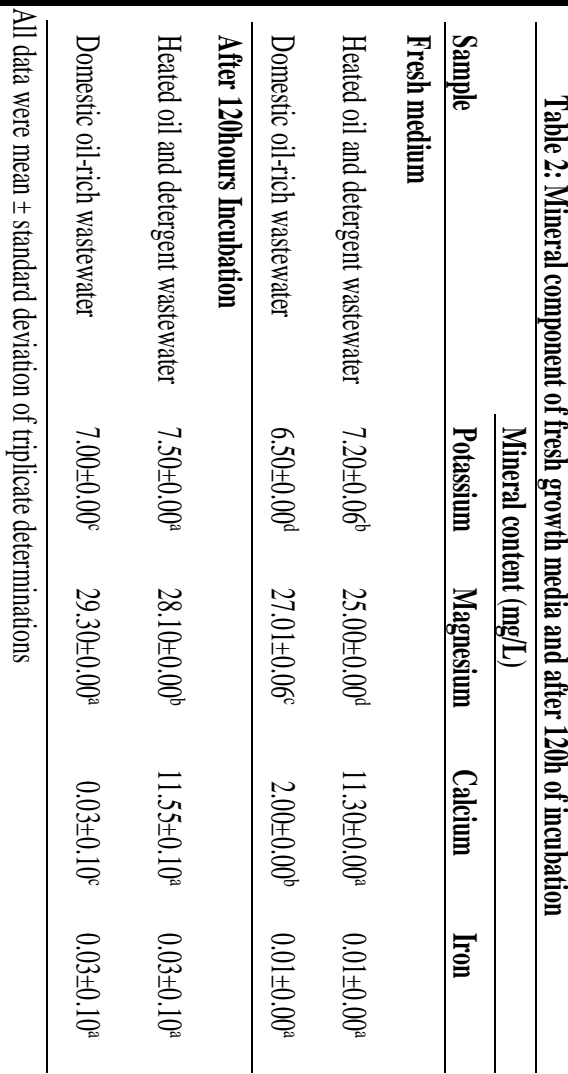

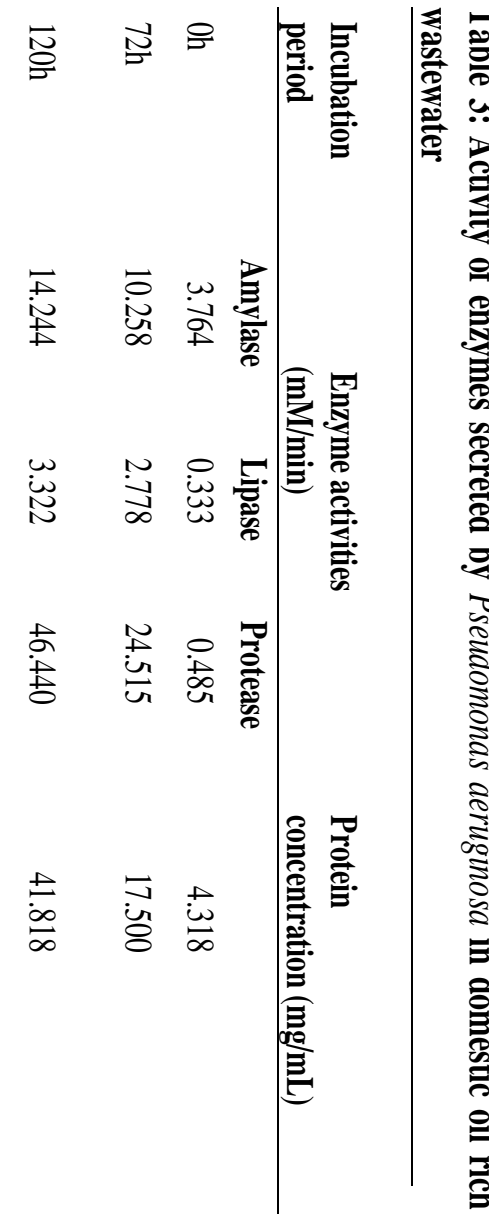

REFERENCES

[1] Adebowale, K. O. and Bayer, E. (2002): Active carbons from low temperature conversion chars. Electronic Journal of Environmental Agriculture and Food Chemistry, 7 (11): 3304-3315.

[2] Adeolu, A. T. and Enesi, D. O. (2013): Assessment of proximate, mineral, vitamin and phytochemical compositions of plantain (Musa paradisiaca) bract an agricultural waste. International Research Journal of Plant Science, 4 (7): 192-197.

[3] Adeyemo, O.K. (2003). Consequences of pollution and degradation of Nigerian aquatic environment on fisheries resources. The Environmentalist, 23, 297306.

https://doi.org/10.1023/B:ENVR.0000031357.89548. $\mathrm{fb}$

[4] Akpan, A.W. (2004). The water quality of some tropical freshwater bodies in Uyo (Nigeria) receiving municipal effluents, slaughter-house washings and agricultural land drainage, The Environmentalist, 24: 49-55.

https://doi.org/10.1023/B:ENVR.0000046346.93401. $5 \mathrm{c}$

[5] AOAC, (2005). Official Methods of Analysis.18th Ed Association of Official Analytical Chemists International, Gaithersburg, MD, USA, Official Method, 2005

[6] Berfield, P., Colowick, S. P. and Kaplan, N.O. (1995): Amylase. In: Methods in Enzymology. Academics Press, New York, Pp. 149-158

[7] Effiong, G. S., Ogban, P. I., Ibia, T. O. and Adam, A. A. (2009): Evaluation of nutrient-supplying potentials of fluted pumpkin (Telfaria occidentalis) and Okra (Abelmoschus esculentus). Academic Journal of Plant Science, 2: 209-214.

[8] Fadile, A., El Hassani, F.Z., Aissam, H., Merzouki, M. and Benlemli, M. (2011). Aerobic Treatment of Lipid-Rich Wastewater by a Bacterial Consortium. African Journal of Microbiology Research, 5 (30): 5333-5342

[9] Irina, S. and Yana, T. (2010): Bioaugmentative Approaches for Dairy Wastewater Treatment. American Journal of Agricultural and Biological $\begin{array}{llll}\text { Sciences, } & 5 & \text { (4): }\end{array}$ https://doi.org/10.3844/ajabssp.2010.459.467.

[10] Kshirsagar, A.D. (2013). Application of Bioremediation Process for Wastewater Treatment Using Aquatic Fungi. International Journal of Current Research, 5: 1737-1739.

[11] Lapygina, E.V., Lysak, L.V. and Zvyaginstsev, D.G. (2002): Tolerance of soil bacterial complexes to salt shock. Journal of Microbiology, 71: 143-147. https://doi.org/10.1023/A:1015181717601

[12] Laura, J.S., Ajit, S. and Jyoti, R. (2013): Toxicity Impacts of Sewage Effluent on the Amylase Activity of Pigeon Pea (Cajanus cajan L.) Plant. International Journal of Development Research, 3 (4): 018-020. 
[13] Lotrakul, P. and Dharmasthiti, S. (1997): Lipase production by Aeromonas sobria LP004 in a medium containing whey and soybean meal. World Journal of Microbiology and Biotechnology, 13: 163-166. https://doi.org/10.1023/A:1018581512540

[14] Nelson, D.L. and Cox, M.M. (2000) "Lehninger, Principles of Biochemistry" 3rd Ed. Worth Publishing: New York.

[15] Nwachukwu, S.C.U., James, P. and Gurney, T.R. (2001). Inorganic nutrient utilization by adapted Pseudomonas putida used in the bioremediation of agricultural soil polluted with crude petroleum. Journal Environmental Biology, 22: 153-162.

[16] Odeyemi, A.T., Aderiye, B.I. and Adeyeye, E.I. (2011). Changes in the microflora and chemical components of domestic oil-rich wastewater. Journal of Microbiology, Biotechnology and Food Sciences, 1(1): 126-147.

[17] Odeyemi A.T., Aderiye B.I. and Bamidele O. S. (2013). Lipolytic Activity of some Strains of Klebsiella, Pseudomonas and Staphylococcus spp. from Restaurant Wastewater and Receiving Stream. Journal of Microbiology Research, 3(1): 43-52. DOI: 10.5923/j.microbiology.20130301.07.

[18] Odeyemi, A.T. Aderiye, B.I., Adeyeye, E.I., E. Donbraye, E and Faleye, T. (2014). Lipolytic Activity and Molecular Identification of Pseudomonas aeruginosa and Lysinibacillus sphaericus Isolated from Domestic Oil Rich Wastewater. British Microbiology Research Journal, 4(4): 392-404. https://doi.org/10.9734/BMRJ/2014/6587

[19] O'Mahony, M.M., Dobson, A.D., Barnes, J.D. and Singleton, I. (2006). "The use of ozone in remediation of polycyclic aromatic hydrocarbon contaminated soil". Chemosphere (2): 307-314. https://doi.org/10.1016/j.chemosphere.2005.07.018

[20] Ong, A.S.H and Goh, S.H. (2002). Palm oil: A healthful and cost-effective dietary component. Food and Nutrition Bulletin, Vol. 23, No. 1, United Nations University Press. 11-22. https://doi.org/10.1177/156482650202300102

[21] Orapin, B., Achara, K. and Suptawee, F. (2002): Biotreatment of High Fat and Oil Wastewater by Lipase Producing Microorganisms. Kasetsart Journal (Natural Science), 36: $261-267$.

[22] Saifudin, N. and Chua K.H. (2006). Biodegradation of Lipid-rich Waste Water by Combination of Microwave irradiation and Lipase Immobilized on Chitosan." Biotechnology, 5 (3): 315- 323. https://doi.org/10.3923/biotech.2006.315.323

[23] Tchobanoglous, G. and Burton, F.L. (1991). Wastewater Engineering: Treatment, Disposal and Reuse (3rd edn) Metcalf and Eddy Inc., McGraw-Hill New York, 1334 pp.

[24] Xia, W. X., Li, J. C., Zheng, X. L, Bi, X. J. and Shao, J.L., (2006).) Enhanced biodegradation of diesel oil in seawater supplemented with nutrients. Engineering

in Life $\quad$ Sciences, 6: 80-85.
https://doi.org/10.1002/elsc.200620113

[25] Xue, L., Famous, E. Jiang, J. Shang, H. and Ma P. (2016). Experimental Survey on Microbial Bioremediation of Food Wastewaters. International Journal of Scientific and Research Publications, 6 (9): 110-118.

[26]Zhu, X., Venosa, A.D., Suidan, M.T. and Lee, K. (2001) Guidelines for the bioremediation of marine shorelines and freshwater wetlands, Land Remediation and Pollution Control Division, National Risk Management Research Laboratory of the U.S. Environmental Protection Agency.

[27]Zulaikha, S., Lau W.J., Ismail A.F., Jaafar J., (2014). Treatment of restaurant wastewater using ultrafiltration and nano-filtration membranes. Journal of Water Processing Engineering, 2: 58-62. 